\title{
Employment Relations and Human Resource Management
}

\section{Brian Harney, Tony Dundon and Adrian Wilkinson}

\section{Introduction}

Employment Relations has both informed and been influenced by key shifts in our understanding about how people at work are managed. One significant development in the field of employment relations (ER) concerns the prominence of Human Resource Management (HRM). Since the mid-1980s HRM has been 'contested' yet also recognised as the 'conventional' academic perspective for analysing the management of employment and all its associated relationship tensions and ambiguities (Keenoy, 2007). HRM has equally been diffused widely into practice and many see HR as a legitimate and professional career choice (Tamkin, Reilly, \& Hirsh, 2006). The traction of HRM has been underpinned by a colonisation of business school content, with dedicated undergraduate specialisms and postgraduate level qualifications in HRM replacing more traditional employment relations provisions. Professional bodies, including the Chartered Institute of Personnel Development (CIPD) and the Society for Human Resource Management (SHRM), have created HRM norms and gold standards while promoting the beneficial impact of HRM for individuals, organisations and society (Kochan, 2007). The current CIPD tag line of "championing better work and working lives" is indicative of this broad ambition, even though scholars point out that these claims may be indicative of rhetoric than actual reality (e.g. Legge, 2005; Thompson, 2011).

Proponents of HRM link its ascendancy to the performance benefits it can yield for firms in enhancing competitiveness and realising strategic advantage. From this view HRM is very much a relative of strategic management (Jackson, Schuler, \& Jiang, 2014); typically seeing matters through the eyes of managers and shareholders (rather than workers and other 
stakeholders). In some measure HRM filled the lacuna left by former industrial relations research which afforded limited attention to the role, impact and dynamics of management (Dundon \& Rollinson, 2011). Others have focused more vehemently on HRM as distinct from personnel management (Storey, 1995), or as a natural extension of it (Torrington, Hall, Taylor, \& Atkinson, 2014). These fault lines of debate have been reflected in significant research efforts. Early HRM researchers sought empirical evidence to explore the nature and diffusion of HR practices, before seeking to demonstrate its viability and assessing its contribution to key organisational and employee outcomes. This latter HRM-performance agenda has dictated much of the recent terms of reference for HRM researchers.

The extent to which HRM can be differentiated from or subsumes employment relations will very much depend on the definition of HRM. Explorations of HRM as an exclusive and distinct approach to managing people are evidenced in literature focusing on highcommitment management, high involvement management, best practice HRM, and High Performance Work Systems (HPWS) (see Wall \& Wood, 2005). A more inclusive understanding can be found from one leading outlet for HRM, the Human Resource Management Journal, which highlights an all-encompassing scope in seeking "to publish scholarly articles on any aspect of employment studies but especially those focused on issues related to the management of people at work. Articles should make a substantive contribution to contemporary issues..." (our italics). ${ }^{1}$ There are however varying levels of emphasis in research and approach. A ten year content analysis of the leading US based journal, Human Resource Management, finds a dominance of keywords such as strategic HRM, selection, careers, leadership, turnover and firm performance. It is only beyond the 40 most frequently used keywords where one find evidence more aligned with employment relations e.g. the

\footnotetext{
${ }^{1}$ http://onlinelibrary.wiley.com/journal/10.1111/(ISSN)1748-8583/homepage/ForAuthors.html
} 
employment relationship, trade unions, conflict, bargaining power, politics, and labour shortages (Townsend \& Wilkinson, 2014).

This chapter seeks to locate the emergence and significance of key intersections of HRM and ER. In so doing the first section of the chapter traces the origins of HRM, highlighting the importance of longstanding domain assumptions which formed the conceptual heritage of the term. The second section of the chapter explores three waves of research that have characterised the field since the mid-1980s, including an emphasis on strategy, HRMPerformance linkages, and employee outcomes. The final section of the chapter draws on a 5C framework to provide a critical evaluation of HRM. Overall, this serves to illuminate the value of more employment relations grounded understanding and on-going conversation between related modes of thinking about the management of people at work in contemporary society.

\section{Origins and Domain Assumptions of human resource management}

It is difficult to find a consensus on the precise origins of HRM (Kaufman, 1999). Gospel (2009) makes a useful distinction between the historically occurring activity of human resource management (lower case), as distinct from the specific conceptualisation of Human Resource Management (upper case) that emerged in the mid-1980s. Focusing on the former understanding, the industrial revolution served as a key catalyst for the development of specific techniques for people management as a factory model of employment mandated new modes of working and organising labour. This heralded the beginning of the mass producing capitalist enterprise moving from direct control to more technical systems, founded on a clear separation between the owners of capital and waged employee labourers. The period saw the rise of a more professional 'managerial' class, essentially acting as agents for and on behalf 
of owners in controlling and managing people under the emergent factory system. The era was also characterised by low wages and very poor working conditions, which were confounded by weak labour power and the absence of a vehicle for collective mobilisation or resistance (Niven, 1967).

There were some shades of light in this early industrial context, however, as more enlightened employers, frequently guided by entrenched moral values or religious beliefs, looked to better the conditions of employment for their workers. A frequently highlighted forerunner to contemporary emphasis in HRM comes from the Quaker tradition which emerged in the late nineteenth century as exemplified by the likes of Cadbury, Fry's and Rowntree's. These were welfare orientated organisations that employed dedicated welfare officers and encouraged worker participation in committees examining issues such as health and leisure time. In a similar vein, as early as 1817 social reformers such as Robert Owen looked to place minimal age thresholds on child labour in factories, while also calling for a more balanced work-day via the slogan "Eight hours labour, Eight hours recreation, Eight hours rest". At this time these social and industrial welfare programs became a place of pilgrimage for statesmen and social reformers, whilst also illustrating to the governing classes that philanthropy could be reconciled with profit-making (Cole, 1930). These more progressive employers still provide a context for academic pilgrimage today, representing an opportune basis for HRM researchers to highlight an employee wellbeing-orientated legacy.

If the industrial revolution provided the initial impetus for the specific consideration of employment and management related issues, this tendency was solidified via the scientific management movement popularised by Frederick Winslow Taylor (1856-1917) and subsequently manifest as Fordist production. Taylor is frequently termed the father of modern 
management theory for his role in introducing practicable, replicable, standard and efficiency driven means to manage production processes and employees therein. The imprinting logic of many HRM practices - from sophisticated recruitment and selection, a division of labour job design system, pay for performance along with talent planning - can found in the control rationality of scientific management. Scientific management had the goal of eliminating uncertainty and reducing any variability in the system. Employees were conceptualised as mere cogs in an industrial system. This not only reflected the engineering mind-set of Taylor, but also a derogatory attitude to the immigrant labour that compromised much of the workforce at the time (Grey, 2009). Whilst scientific management brought forward practices founded on transparency and formality, it also provided a clear divide and on-going justification for the separation of those tasked with policy formation (management) and those responsible for implementation (employees). Overall, in many ways scientific management serves as the ultimate prescriptive template for aligning desired organisational goals and objectives with the means of organising the workforce to realise these. It is perhaps unsurprising therefore that in the 1920 s the need to take a strategic approach to managing people in the workplace was already articulated by many organisations (Kaufman, 2007).

With its foundation on rational efficiency and a means-end logic, it is perhaps inevitable that scientific management would be subject to staunch critique. In a practical sense, employees working under such conditions were subject to boredom, frustration, minimal autonomy and alienation which ultimately became manifest as forms of resistance and employee turnover (Mowday, Porter, \& Steers, 1982). A solid stream of workplace research gradually emerged unpacking these dynamics and re-introducing human agency into the equation, including the Human Relations movement. Building on its origins in Elton Mayo's Hawthorne experiments, Human Relations stressed the imperative of paying due attention, not simply to 
the physical conditions of work, but equally to employee needs and motivation in the form of group dynamics, informal recognition, and individual expectations. HRM has a close allegiance to the behavioural insights and modes of understanding associated with the Human Relations movement. Indeed, HRM's emergence and significance as a contrast to traditional personnel management can be seen as echoing this earlier historical surge from scientific management towards a more normative form of control (Barley \& Kunda, 1992).

\section{Domain Assumptions}

While often depicted as vastly contrasting modes of people management, in reality both scientific management and human relations were founded on common domain assumptions which would be readily assimilated into HRM. Both scientific management (with its rationality on 'economic logic') and human relations (with a focus on 'social legitimacy') were underpinned by a fundamental desire to control the labour process in order to enhance productivity and maximize private profit. As a basis for understanding how this may be achieved, both had a penchant for a hard and positivistic science paradigm, with a belief that the tasks of employees could be accurately defined, then measured and assessed with specific predictability. Finally, an underlying ideological imperative of both approaches was that organisations should operate without any countervailing force or alternative voices, so that all employees were aligned to the objectives of the organisation, i.e. a nascent form of unitarism. Thus although Human Relations is frequently touted as a being more humane in its treatment of employee owing its social and psychological antecedents compared to the harder economic basis of scientific management, at its core was a desire to "discover how psychology could be used to raise productivity, resist unionization, and increase workers' cooperation with management" (Kiechel, 2012: 66). Indeed, a deeper historical inspection provides further insights into the managerial biased undertone revealing that both Taylor and Mayo had 
commercial vested interests which were intertwined with a nascent business school agenda underpinning the ideology of leading industrialists Joseph Wharton and John D. Rockefeller respectively (Bruce \& Nyland, 2011). In his wonderful excavation of the social and historical context framing the Hawthorne studies, Hassard (2012: 1434) suggests that "the narrative developed by Mayo's research group emerged as much from internal politics at Harvard as scientific evidence from Hawthorne". In surfacing domain assumptions related to performance maximization, faith in the scientific paradigms and a managerialist heritage, these early schools of thought bare a forceful imprint in how mainstream (prescribed best practice) HRM conceptualises work and work relations as something for the good of a promarket ideology (Godard, 2014; Harley, 2015;Thompson, 2011).

\section{Contemporary emergence of HRM}

Personnel management emerged as a welfare orientated role addressing the needs of employees, but equally as a dedicated function necessitated by more large scale, diversified organisations (Chandler, 1962). By the 1970s this was accompanied by a requirement for specialist expertise to deal with a growing stream of legislation governing the employment relationship (e.g. in areas such as pay, hours, holidays, equality, redundancy and employment protection). Yet this growth in demand for personnel specialists did not automatically equate to an elevated status for the function. Early commentary found personnel management to be a dumping ground for many unwanted tasks, heavily criticized for being a combination of the functions of file clerk, social worker and firefighting (Drucker, 1954). Personnel management was also perceived in a gendered fashion. In particular, it had a feminised welfare role which was contrasted with the more male like technical professions of finance and accounting, or indeed with the bargaining and negotiation associated with employment relations (Legge, 1995). Even less complimentary impressions come from Harry Callaghan; the no-nonsense 
San Francisco police detective played by Clint Eastwood in the movie series Dirty Harry, when he responds to his internal transfer to personnel: "What? To Personnel! That's for arseholes"2.

Debates and tensions concerning HRM meanings were evidenced in models which highlighted the diversity of personnel practice and the variety of roles carried out by managers. Taking Tyson and Fell's (1986) building analogy as an example, key personnel management roles ranged from an administrative 'clerk of works', through to a more sophisticated, employee focused 'contracts manager' and finally the 'architect' with significant influence operating at the level of strategy and top management. In practice, personnel management was still largely seen as an administrative function dealing with the 'labour problem' rather than contributing to strategic goals. During the 1970s in particular, much of the personnel manager's time was consumed with employment relations firefighting. In many ways with this descriptive, administrative and reactive stereotype, personnel management served as the perfect foil to set out the virtues of the new HRM orthodoxy as it emerged with force in early 1980s (Wilkinson, Bacon, Redman, \& Snell, 2009).

HRM was a founded on a mantra that it represented $a$, if not the, means to generate competitive sustainable advantage for firms. This strategic discourse emanated in the context of intensive global competition, most notably from Japan, and the emergence of more peopleintensive service and knowledge-based industries. Academic models originating from the likes of Harvard Business School (Beer, Spector, Lawrence, Mills, \& Walton, 1984) and Michigan (Fombrun, Tichy, \& Devanna, 1984) lent credence and practitioner impetus to

\footnotetext{
${ }^{2}$ See Torrington et al, 2014; or YouTube clip of the scene: $h$ htps://www.youtube.com/watch?v=qvG3R-xOMzE
} 
HRM. Overall, there was a consensus that organisations were best served when employees "were given broader responsibilities, encouraged to contribute, and helped to take satisfaction in their work" (Walton, 1985: 77). The focus shifted from controlling workers to eliciting commitment and creating an infrastructure and environment whereby employees could flourish ultimately yielding "tangible dividends for the individuals and the company" (Walton, 1985: 77). This commitment emphasis also served to fill some of the analytical space left void by ER scholarship which tended to privilege the conflict dimension of the employment relationship to the neglect of more mutual or collaborative aspects (Ackers \& Wilkinson, 2003; Delbridge, 2007). HRM flipped the terms of reference forcefully to the other extreme, privileging unitarism as the presumed basis and outcome of HRM prescriptions (Geare et al., 2014).

It is perhaps unsurprising that early contributions examining the rise of the new HRM were concerned to define it and specifically contrast it with a more traditional approach to personnel management (e.g. Guest, 1987). Beyond the US, HRM was (initially at least) received with more scepticism. HRM was at once seen as commitment orientated approach to people management (Storey, 1995), 'a wolf in sheep's clothing' (Keenoy, 1990) or as 'old wine in a new bottle' (Legge, 1995). Others highlighted an undercurrent of individualisation of the employment relationship and purposeful marginalisation of trade unions (Nolan \& Wood, 2003). Indeed HRM's emphasis on management, strategy and enterprise coalesced neatly with the prevailing economic and ideological consensus of the 1980s born of Reagan in the US and Thatcher in the UK. The theoretical significance of HRM was that it could serve as a substitute for a traditional employment regulatory approaches. Where an exclusive definition of HRM was offered it was somewhat easier to differentiate HRM from its predecessors. Picking up the emphasis on commitment and competitive advantage, Storey 
proffered a definition of HRM as "a distinctive approach to employment management which seeks to achieve competitive advantage through the strategic deployment of a highly committed and capable workforce, using an integrated array of cultural, structural and personal techniques" (1995: 5).

While definitional debate continued and empirical evidence of HRM remained patchy at best, there was some consensus on what normative HRM should look like. In addition to its focus on employee commitment, a core argument was the necessity that the way people were managed should support and align with organisational strategy. In terms of understanding the connections with the management of employment relationships, HRM was inherently unitarist, with policies and practices driven by business needs above all other interests (Wilkinson, Redman \& Dundon, 2017). Former ER traditions such as the rise in specialist bargaining expertise was considered reactionary to issues arising from mass union growth, while the new HRM targeted operational responsibilities at individual line managers who were often intolerant of distant personnel experts removed from immediate demands of getting products out the door. In business terms, HR was to be a strategic business partner advising on strategy, including via board representation, while local managers who know best how to do a job become empowered to implement change. However, clear lines of differentiation between old personnel and new HRM were premised more on normative ideals rather than an empirical reality (Legge, 2005). In strategic terms HRM has always been a lower order factors compared to corporate or business objectives (Boxall and Purcell, 2011). In moving beyond the impasse, efforts to develop and legitimise HRM can be characterised by three waves of understanding and emphasis, all of which formed part of an on-going journey to formulate and refine the meanings of HRM and how its connects with firm decision as well as employee wellbeing concerns. 


\section{Matching models}

Matching models of HRM represent a form of contingency theory, guided by the implicit assumption that the most successful organisations are those that display a 'Chinese box' type consistency between the external environment and internal organisation (Miles \& Snow, 1984). Deciphering HRM's linkage to strategy has been core of the HRM agenda since the mid-1980s. An early and influential development was the Michigan model of 'Hard HRM' developed by Fombrun et al. (1984). This model detailed a tight and calculative (hard) fit between the business needs of organisations and the way people were managed to ensure optimal alignment and maximum employee effort and performance. In this model the focus was on Human Resource Management, with HRM operating via strict rules related to selection, training and reward and employees ultimately judged as factors of production to be assessed on purely efficiency grounds. By contrast, a matching model developed at Harvard Business School emphasised more 'soft' variants of HRM, whereby employees were treated as assets to be nurtured and developed. This $\underline{\text { Human }}$ Resource Management approach pioneered by Beer et al. (1984) included multiple stakeholder interests (including government and trade unions), multifaceted employee outcomes and also long term implications for individuals and well-being. While considered to be more analytically grounded, it was more difficult to specify this range of descriptive elements and also evaluate more softer dimensions and human attributes (Redman, Wilkinson, \& Dundon, 2017). This is a problem that continuously haunts HRM meaning that much of this richer heritage has been neglected. A narrower conceptualisation of HRM illuminating the direct linkages and desired role behaviours mandated of various organisational strategies (frequently referred to as 'best fit') became the core focus of HRM by the late 1980s (e.g. Schuler and Jackson, 1987) 
Matching models were intuitively appealing to practitioners and enabled HRM researchers to leverage the legitimacy of related fields such as strategic management. Critiques of matching models claim that they overestimate the clarity and rationality of the process. Strategy may often emerge retrospectively, while rigid 'fit' may actually hinder the innovativeness and flexibility mandated for success. Assuming consensus on end objectives may be a flawed starting point as this process is likely to be messy, contested and shaped by power relations. As long standing critiques of contingency theory note "politics cannot be simply left to the end as part of the problem of application" (Wood, 1979: 342). Underpinning matching models is an implicit determinism, leaving little room for the agency of HR managers (or workers and their representative bodies), who are expected to choose and operate from a predetermined and narrow palette of HR options. Rich qualitative case studies, even of leading edge organisations, found little of what matching models would predict with commentators indicating that firms actually express a preference for more 'flexible' approaches (Tyson, 1997). While extensive research claims to have demonstrated the mediating role of strategy in enhancing the HRM performance linkage (Youndt et al., 1996), results have been subject to ambiguous definitions and varying interpretations. Arthur's (1992) study of steel minimills claims a significant association between HRM systems and business strategy choices, yet $40 \%$ of mills in Arthur's study with a strategy of differentiation did not have a matching commitment based HRM system (1992: 502). In the meantime, authors have put forward accounts depicting fit as more multifaceted and complex than a narrow strategy-HRM relationship would allow for (e.g. environmental fit and legitimacy). Matching models clearly enhanced the business case for HRM, although rather than being addressed, key conceptual and empirical concerns were ignored or overshadowed by the HRM-Performance wave of scholarship. 


\section{HRM and Performance}

If matching models privilege exclusivity for a managerial class, the last two decades have been characterised by attempts to validate precisely how important HRM is for organisational profit. HRM-performance research has been consumed by attempts to demonstrate the positive relationship between HRM practices and organisational performance. The HRM labels used in this type of research - High Performance Work Systems, Best Practice HRM, High Commitment Management - signal above all else some demonstrable boost to a firm's bottom line via people management policies. This line of research found a theoretical bedfellow in the Resource-Based View (RBV) of the firm, which argues that the essence of advantage resides in the internal capabilities and processes of organisations, including the way people are managed (Harney \& Trehy, 2016). While building on the logic of matching models, HRM-performance research is much more universalistic in its argument, holding that certain human resource practices have a direct and positive impact on organisational performance irrespective of the context in question. Initially, the universalistic focus was on single HR practices such as pay and staffing. Over time, research evolved to examine how mutually reinforcing bundles of HRM practices could have a synergistic impact on financial performance. Typical HR practices advocated as part of such bundles include sophisticated recruitment tests, internal promotions, job security, extensive training, and performance related pay schemes. A key watershed in the HRM performance movement was research by Mark Huselid (1995) which demonstrated that the use of a high performance work system (an index of 13 HRM practices) was significantly and positively related to lower turnover, and higher profits, sales, and market value for the firms studied. Overtime researchers have tried to hone in more precisely on the size effect and impact of HRM (Jiang, Lepak, Hu, \& Baer, 2012). The HRM-performance debate has clearly shaped the terms of reference in HRM, with 
efforts at extension and replication remain common yet also contestable (Pauwee, Guest \& Wright, 2013).

The HRM performance wave of research has played a huge role in facilitating HR managers to demonstrate impact (Wall \& Wood, 2005). This discourse has been eagerly embraced by consultants in justifying their interventions. However, many still grapple with what precisely constitutes performance practice bundles, especially if they are to be held up as a best practice or a distinct variant to earlier paradigms of ER. While there is agreement at a broad level in the principles of enhancing employee motivation, skill and ability from better people management processes, these same principles informed much previous industrial relations analysis since the Donovan Commission in the 1960s in Britain (Seifert, 2015). In contemporary HRM studies, however, there appears to be contradictory prescriptions as to the precise mix of practices actually involved, and little consensus on how they should be measured (e.g., indexes, scales, clusters) (Posthuma, Campion, Masimova, \& Campion, 2013).

Definitional issues aside, if such HRM practices are so beneficial, what explains their limited diffusion across organisations? Clearly, the magnitude of the economic benefits from adopting new HRM systems will be qualified by the vagaries of market forces, contextual influences, and institutional factors (Wilkinson, Redman \& Dundon, 2017). It may also be the case that financial performance is simply too distal to capture the impact of HRM interventions. Attempts also tend to ignore the sector specific nature of turnover and performance, while also relegating discussion of intensified competition to something controllable; a rationale supportive of the adoption of best practices rather than something that may actually militate against them. HRM-performance arguments are largely founded on 
certain types of firms (large, private sector) from certain regions (Anglo-Saxon) and so the significance of institutional context is not given due acknowledgement. As Boselie et al (2001) points out, high commitment practices that are discretionary under neo-liberal regimes such as the USA and the UK are often part of the legislative framework elsewhere, such as in the Netherlands. In their review of low-wage work across a number of high-income countries in Northern Europe, the UK and the USA, Appelbaum and Schmitt (2009) argue that institutions including the legal framework and the power of organised labour have a strong influence over the take-up of HRM. Thus high commitment HRM depends not just on employers but also corporate governance and actors at national as well as organisation level. (See Marchington et al 2016 70-71).

A long standing debate is whether HRM leads to performance or whether the impetus flows in the opposite direction i.e. firms success results in more sophisticated HRM. Equally concerning is that recent re-examination of key contributions has found their original findings severely wanting. Gerhart's (2007) review of Ichniowski et al., (1997) finds nothing to support a performance impact from HR bundles, while Porter and Siggelkow's (2008) reassessment of MacDuffie (1995) dismisses the notion of a universal impact of HR practices (with the one exception of formal teams), suggesting that HR practices exhibit significant 'contextuality'. This is important as it has long been recognised that employers may purposefully deploy unique employment practices as a distinctive means of product market competition (Brown, 2008). A core criticism of HRM performance studies is that they represent the unitarist assumptions of HRM scholarship, writ large. Until recently HRMperformance scholarship was exclusively about management (HR practices) for management (various performance outcomes) with limited appreciation of the dynamics of the employee side of relationship. 


\section{Employee-centric HRM}

Early content analysis revealed HRM-performance studies paid scant attention to workers (Wilkinson, Redman \& Dundon, 2017). Employee perspectives have been gradually incorporated into analysis, largely as part of efforts to provide more rigorous and robust explanations of the HRM-performance relationship or 'unlocking the black-box' (Jiang, Lepak, Hu, \& Baer, 2012). This wave of more employee-centric research has been buffered by a (renewed) emphasis on a socio- psychological dynamic of the employment exchange relationship (Dundon \& Rollinson, 2011), with recognition of various collective and individual workforce orientations at play which affect the 'strength' of the HR system (Bowen \& Ostroff, 2004). Research has pointed to the importance of line managers as key intermediaries in the delivery of HRM (Harney \& Jordan, 2008, Townsend \& Dundon, 2015). In this regard the employee-centric agenda may be seen as seeking to put the worker back in the equation, as active agents capable of shaping their work experiences and the arrangements under which they are expected to generate value and performance (Grant and Shields, 2002; Heffernan \& Dundon, 2016).

In contrast to the unitarist penchant in most HRM literatures, contemporary employee-centric assessments tend to paint a more pluralist perspective of the divergent cooperative and antagonistic basis of work relations (Boxall and Purcell, 2011). Research in this area has countered the assumed mutual 'win-win' argument in much extant HRM and shown that HPWS impacts could have been achieved through work intensification (Ramsay, Scholarios, \& Harley, 2000). Analysis now supports the idea of competing hypothesis and a recognition of key tensions and contradictions likely to characterise the HRM performance relationship (Ehrnrooth \& Björkman, 2012). Moreover, beyond many surface level 
prescriptions there is evidence of empirical tensions. Research has shown that even where HR has achieved the status of a fully integrated 'strategic partner', this may not necessarily be beneficial for employees; indeed, it can lead to feelings of estrangement and frustration (Hope-Hailey, Farndale and Truss 2005). Kochan (2007) bemoans the alignment of HR and business interests, arguing that this is the root cause of the lost credibility and lack of trust in HR professionals. Marchington (2015) adds that the problem lies in the HRM function losing sight of its principle welfare tradition and instead becoming obsessed with 'looking up' to the boardroom to stress short-term performance validity for the existence of HR. Further, it is poised that financialised neo-liberal modes of accumulation has meant that many managers fail to deliver on their side of the bargain, owing to global economic pressures and demands out of their control (Thompson, 2013). Lepak and Snell's reasoning is equally instructive; "managers do not have the necessary resources to invest in developing knowledge based employees. In particularly dynamic environments, firms may not believe they will be able to fully recoup human capital investments in even their core workers" (2002: 537). Critical accounts have long stressed that HRM operates as a pseudo-gemeinschaft with arguments that perceived best practice HRM actually leads to work intensification and negative employee outcomes.

\section{ER and HRM: 5Cs for conversation}

This chapter has presented the evolution of HRM from its early origins through to contemporary waves of research and the desire for performance-enhancing employment paradigms. Despite this development many commentators provide damning indictments of progress pointing to the poor status and strategic influence of the HR function (Kaufman, 2012; Kochan, 2007). The performance agenda that has dictated recent focus exemplifies a 
field struggling to demonstrate its role and impact (Guest, 2011). In order to expand on some the deficiencies of extant HRM and explore insights from ER, this section draws on the 5Cs of 'complexity, context, contingency, causality and critique' as an organising framework. The 5Cs have been identified as 'central to the concerns' of researchers studying the management of people at work (Delbridge \& Whitfield, 2007).

\section{C1 Complexity}

A common critique directed at HRM is that it provides a sterile account of HRM interventions. Research into HR in some of the top performing firms has found an emergence, highlighting an entangled nature of formal policy and informal dynamics on the shopfloor (Gratton, Hope-Hailey, Stiles, \& Truss, 1999). Recognition of a disparity between intended and realised HRM practice has fostered a dedicated line of research founded on the unitarist assumption that this gap can be easily bridged or minimised, largely through more or better management, or via ready-made solutions to 'fix' some managerial or organisational deficiency.

An alternative ER approach would suggest that such disparity leaves analysis open to the concept of emergence, informality and complexity, not something of a defined problem to be fixed but reflective of the diverging interests and structured antagonism at the heart of the employment relationship (Edwards, 1986; Dundon \& Dobbins, 2015). HRM decisions may not always be introduced or enacted as a result of strategic foresight as traditionally understood, but rather reflect tactical optimums strived for by management who often fumble or just 'muddle-through' on a day-to-day basis (Lindblom, 1959). A concern with complexity also allows for the informality of practice that substitutes for, or fills, the silences of formal policy (Edwards, 1995). In reality, managers in all organisations navigate between rationality, 
formality, personal preference and idiosyncrasy as the occasion demands. A long heritage of workplace studies provides a wealth of concepts related to the 'leeway function of rules' (Gouldner, 1954) or the role of custom and practice (Brown, 1972). Overall, the dimensions of complexity (emergence, informality and conflicted collaboration) point to a nuanced world of HRM which cannot be collapsed neatly into fixed practices, categories or outcomes (Marchington \& Suter, 2013).

\section{C2 Context}

With its universalistic emphasis HRM offers scientific insights; however, these can also be independent of both its mode of operation and place of application. There is a tendency to reify and abstract features of organisations, imbuing them with formal characteristics in the pursuit of rational, predetermined goals. Edwards (2005) contents that 'context sensitive research' holds that HRM cannot be dislocated from the totality of political and economic relations. These form the enabling conditions for dynamic fluidity of the employment relationship and a means to conceptually enrich $\mathrm{C}$, the complexity issue, previously discussed. A focus on macro-context enables an understanding of HRM as an on-going process constantly being enacted and re-enacted, as opposed to a once off structural intervention. The imperative of this approach is evidenced in an era of 'financialization', previously noted, where financial transactions and relationships external to the organisation (and independent of physical produces or services), are deemed to be defining the employment relationship (Cushen \& Harney, 2016; Applebaum, Batt, \& Clark, 2013). This context exposes the deficiency of imposing a biased preconceived ideal of HRM.

The context in which HRM is enacted clearly matters. Normative prescriptions in HRM (e.g. 'business partner' aspirations or 'championing better working lives') risk becoming de- 
contextualised from the power relations required for them to be realised or constrained. Likewise, employees are not passive recipients of HRM. Needs, demands and previous experiences of employees, including gender and feminisation, are all important factors that will inform the nature of HRM and the way it is applied under segmented labour contexts (Grimshaw and Rubery, 2008). For instance, when examining employee voice in SMEs, Wilkinson, Dundon \& Grugulis (2007:1291) refer to the 'paradox of organisational action' whereby "social actors inject their own interpretations, meanings and interests which results in a more complex set of social interactions associated with managing human resources". Contextual issues such as the extent of pay dispersion, the size of a firm or the nature of 'give and take' on a shopfloor may hold greater import in understanding employee experiences of work than (pre)judging them on a narrow or pre-defined number of formal HR practices in place. This discussion of context suggests that in order to give meaning to debates, HRM researchers might pay greater attention to work rooted in the traditions of understanding the institutions and systems of work and employment inequalities, while appreciating contextually grounded definitions which are more sensitive to local interpretation and variance.

\section{C3 Contingency}

Except in the form of moderators or limited 'control variables' (e.g. age, sector, unionisation), HRM has been slow to engage with the impact of key contingency variables. More traditional research has long pointed to product market competition and labour market conditions as fundamental to appreciating employment relations. In introducing an emphasis on management actions, HRM has served to overplay managerial rationality and decision making capability and underplayed constraints or structural realities. This is most obvious in the limited attention HR scholars have paid to the impact from the likes of legal regulation, 
trade union modernisation or informal modes of labour resistance and misbehaviour on ER (van den Broek \& Dundon, 2012). An emphasis on contingencies in this situation is not analogous to the over simplified contingency or best fit matching models of the $1980 \mathrm{~s}$, but rather an appreciation of the necessity for research to allow for, and accommodate, uneven dynamic interventions between a firm, its environment and among its stakeholders. Kaufman (2010) has made a strong case for a demand-driven conception of HR, noting that researchers should be less consumed by whether a certain type of HRM is inevitable or the degree of investment in a practice, and instead focus on the more 'fruitful problem' of developing theoretically-informed accounts that consider patterns of diffusion and the actual practices utilised. The desired performance outcome of firms is also likely to be a relative concept, wherein financial performance or profit maximization may not always be objective criteria owing to differences on context (e.g. sector or ownership types) and complexity (e.g. informality).

\section{C4 Causality}

HRM has been dominated by a 'big science' approach to empirical research (Wall \& Wood, 2005). This is frequently based on counts of practices, a quest for event regularities and theoretical exploration via mediation, moderation or structural equation modelling. This line of inquiry offers a limited basis for understanding the various contexts and complexities under which HRM is actually enacted. Moreover, correlation between variables is often falsely equated with explanation and confirmation (Harney, 2009). By contrast, historical workplace studies exhibit a richer form of analysis, involving in-depth case analysis founded on uncovering the processes of 'complex causality' (George \& Bennett, 2004), and its project of explaining the observed features of the 'real world', by reference to the underlying mechanisms that are responsible for them. Indeed, it has been long noted that a complete 
understanding of the employment relationship requires that we analyse the social relations that underpin them. Alternative modes of understanding in HRM including more intensive and longitudinal research would ensure that explanatory accounts are privileged, that processes of HRM in firms are adequately contextualised, and that complexity is accommodated. Ultimately HR practices and rules have to be interpreted in action (Edwards, 2003). Greater analytical purchase may also help with the incorporation of dimensions of well-being, employee voice, organisational democracy, justice and other outcomes which do not sit well the dominant HPWS quantitative paradigm.

\section{C5 Critique}

In addition to the $4 C s$ suggested by Delbridge and Whitfield (2007), the role of immanent critique is a fifth ' $\mathrm{C}$ ' which ought to be of concern for HRM researchers. In one respect this may seem obvious. However, much of the normative HRM models coupled with a prescriptive and managerial bias in a lot (although not all) of its teaching in mainstream business schools, mean a conversation about critical reflection is warranted (Dundon, Cullinane \& Wilkinson, 2017). Immanent critique and the problematization of extant HRM acts not only as a basis to position research but also serves as a reflexive process to ensure HRM researchers do not automatically perpetuate the status quo (e.g. Godard, 1994). Recognition of 'complex' structural layers, 'contextual' diversity and 'causal' ambiguity mean there is scope for ongoing critical dialogue, encouraging sensitivity to contingent processes and events rather than proffering immediate, universal solutions (Edwards, 2005). Current debates in HRM are largely consumed by technical issues which may result in an ideological 'immiseration' of the field of study, including its teaching and practical application across some (although not all) business school programmes (Dundon et al, 2017). With respect to performance there is little recognition of the multiple outcomes initially 
proffered by Beer et al., (1984) and others. Likewise, there is little cross fertilisation from related fields, such as the application of Budd's (2004) analytical prism for understanding the balance of 'efficiency, equity and voice', or the intersectionality of Organisational Behaviour and Employment Relations disciplines to inform 'pro-social silence and voice' within the workplace (Barry \& Wilkinson, 2016). In many ways conceptual advancement in HRM is hindered by a 'consensus orientation' (Keegan \& Boselie, 2006). As a consequence, HRM proponents neglect critical trends found in related fields of ER and Organisational Analysis (e.g. outsourcing, trade unions, conflict management, whistle-blowing, identity, top management fraud) which run counter to untiarist models and frames of reference (Batt and Banerjee, 2012). Concepts such as engagement and well-being also risk being interpreted in a narrow, managerialist fashion at odds with their more holistic, employee-centric origins. As Guest (2017) notes while the dominant models within HRM theory and research have focussed largely on ways to improve performance with employee concerns regarded as a secondary consideration, pressures at work, are creating an increasing threat to employee well-being and if these concerns are to be taken seriously, a different analytic framework for HRM is required.

Overall, many research efforts in HRM typically suffer from a failure to appreciate the key attributes of the 5Cs; 'complexity' is downplayed or (deliberately) eroded by managerialism; 'context' is lacking or deemed homogenous; 'contingencies' are notably absent or superficially controlled; prescriptions are derived from large scale positivist research founded on a simplistic Humean notion of 'causality'; while a consensus orientation overshadows immanent 'critique', all of which can engender the ideological immiseration of the field. Employment Relations, on the other hand, affords greater contextual sensitivity with its 
understanding of reciprocity surrounding an economic, social as well as psychological exchange relationship.

Grounded by these type of insights HRM may be better placed to appreciate the interaction between the structural forces both inside and outside the immediate work milieu that shape the management of those in employment. Of particular utility in this vein is the more inclusive definitions of 'analytical HRM' (Boxall and Purcell, 2008), treating the subject as "those activities associated with the management of work and people in firms" (Boxall \& Purcell, 2008: 1). This is accompanied by a commitment to explain what happens in reality: "taking account for the way that management actually behaves and therefore privileging understanding and explanation over prediction" (Boxall, Purcell, \& Wright, 2007: 4, emphasis added). Important to stress here is the necessity of the process and not to predetermine or dictate the form that any bundle of HR practices will take. This avoids the common problem in much HRM analysis whereby its meaning is exhausted by those who prescribe. Very much connected to this is the important point that analytical HRM moves towards embracing the inevitability of tension and contradiction, and so steps away from a unitarist and exclusively normative managerialist agenda. The power and politics inherent in the operation of the employment relationship is acknowledged through the notion of 'plurality' of goals, interest and strategic tensions (Boxall \& Purcell, 2008). While analytical HRM is seen to hold much promise, it should also be appreciated that it is hardly novel and some of its key principle lessons have an established pedigree in the antecedents of earlier related literatures (Gouldner, 1954; Prandy, Stewart \& Blackburn, 1983; Jain \& Murray, 1984; Gospel, 2009).

\section{Conclusion}


While HRM is often assumed to be ahistorical, this chapter has suggested that HRM is very much informed by its conceptual and ideological heritage, including its connections to deeper social science anchor points of ER. Likewise, the challenges facing the HR practitioner reflect long standing dynamics and tensions inherent to all efforts of managing the employment relationship, however defined. Paradoxically, as much as HR might be criticised for its managerialist focus, it has elevated and sustained the employment relationship as a key means of understanding organisations, where other perspectives have fallen somewhat short. Moreover, 'tactical engagement with HRM' (Jacques, 1999: 216) as the conventional means for analysing the employment relationship provides the basis for informed insights and a balanced assessment about the management of people at work. On the matter of more inclusive definitions, there is scope for mutual influence and an analysis which is sensitive not just to needs and interests of shareholders (employers), but considers the interactions and obligations of a range of stakeholders (workers and others) connected in a complex web of institutional structures and process-driven informalities. This is one means to help avoid the trap of partial understanding born of disciplinary myopia. 


\section{References}

Ackers, P., \& Wilkinson, A. 2003. Understanding Work and Employment: Industrial Relations in Transition: Oxford University Press.

Applebaum, E. and Schmitt, J. 2009. Low wage work in high income countries: labour market institutions and business strategy in the US and Europe, Human Relations, Vol. 62, No. 2, 190734.

Applebaum, E., Batt, R., \& Clark, I. 2013. Implications of Financial Capitalism for Employment Relations Research: Evidence from Breach of Trust and Implicit Contracts in Private Equity Buyouts'. British Journal of Industrial Relations, 51(3): 498-518.

Barley, S., \& Kunda, G. 1992. Design and Devotion: Surges of rational and normative ideologies of control in managerial discourse. Administrative Science Quarterly, 37(3): 363-399.

Barry, M. and Wilkinson, A. (2016) 'Pro-social or pro-management? A critique of employee voice as pro-social behaviour within organisational behaviour', British Journal of Industrial Relations, 54(2): 261-84.

Beer, M., Spector, B., Lawrence, P., Mills, Q., \& Walton, R. 1984. Managing Human Assets. New York: The Free Press.

Boselie, P., Paauwe, J., \& Jansen, P. 2001. Human resource management and performance: lessons from the Netherlands. International Journal of Human Resource Management, 12(7): 1107-1125.

Boxall, P., \& Purcell, J. 2008. Strategy and Human Resource Management (Second ed.). London: Palgrave MacMillan.

Boxall, P., Purcell, J., \& Wright, P. 2007. Human Resource Management: Scope, analysis and significance. In P. Boxall, J. Purcell, \& P. Wright (Eds.), Oxford Handbook of Human Resource Management: 1-16. Oxford: Oxford University Press.

Brown, W. 1972. A consideration of custom and practice. British Journal of Industrial Relations, 10(1): 42-61.

Brown, W. 2008. The influence of product markets on Industrial Relations. In P. Blyton, N. Bacon, J. Fiorio, \& E. Heery (Eds.), Handbook of Industrial Relations: 113-127. London: Sage.

Bruce, K., \& Nyland, C. 2011. Elton Mayo and the deification of Human Relations. Organization Studies, 32(3): 383-405.

Budd, J. W. 2004. Employment with a Human Face: Balancing Efficiency, Equity and Voice,. New York: Cornell University Press.

Chandler, A. D. 1962. Strategy and Structure. Cambridge Mass: M.I.T. Press.

Cole, A. D. H. 1930. The life of Robert Owen: MacMillan.

Cushen, J., \& Harney, B. 2014. Broken promises: Why SHRM does not always work. In B. Harney, \& K. Monks (Eds.), Strategic HRM: Research and practice in Ireland. Dublin: Orpen.

Delbridge, R. 2007. Explaining conflicted collaboration: A critical realist approach to hegemony. Organization Studies, 28(9): 1347-1357.

Delbridge, R., \& Whitfield, K. 2007. More than mere fragments? The use of the Workplace Employment Relations Survey data in HRM research. International Journal of Human Resource Management, 18(12): 2166-2181.

Drucker, P. F. 1954. The practice of management.

Dundon, T and Dobbins, T. (2015), 'Militant Partnership: a radical pluralist analysis of workforce dialectics', Work, Employment and Society, 29(6): 912-931

Dundon, T., Cullinane, N. and Wilkinson, A. (2017), A Very Short, Fairly Interesting and Reasonably Cheap Book about studying Employment Relations, London: Sage. 
Edwards, P. 1995. From Industrial Relations to the Employment Relationship. Relations Industrielle, 50(1): 39-65.

Edwards, P. 2003. The employment relationship and the field of industrial relations. In P. Edwards (Ed.), Industrial Relations: Theory and Practice: 1-36. Oxford: Blackwell.

Edwards, P. 2005. The challenging but promising future of industrial relations: developing theory and method in context sensitive research. Industrial Relations Journal, 36(4): 264-282.

Ehrnrooth, M., \& Björkman, I. 2012. An Integrative HRM Process Theorization: Beyond Signalling Effects and Mutual Gains. Journal of Management Studies, 49(6): 11091135.

Fombrun, C., Tichy, N., \& Devanna, M. 1984. Strategic Human Resource Management. New York: Wiley.

Geare, A., Edgar, F., McAndrew, I., Harney, B., Cafferkey, K., \& Dundon, T. 2014. Exploring the ideological undercurrents of HRM: Workplace values and beliefs in Ireland \& New Zealand. International Journal of Human Resource Management, 25(16): 2275-2294.

George, A., \& Bennett, A. 2004. Case studies and theory development. Massachusetts: MIT Press.

Gerhart, B. 2007. Modelling HRM and Performance Linkages. In P. Boxall, J. Purcell, \& P. Wright (Eds.), Oxford Handbook of Human Resource Management. Oxford: Oxford University Press.

Godard, J. 1994. Beyond Empiricism: Towards a Reconstruction of IR Theory and Research. Advances in Industrial and Labor Relations, 6: 1-35.

Godard, J. 2014. The psychologisation of employment relations? Human Resource Management Journal, 24(1): 1-18.

Gospel, H. 2009. HRM: A historical perspective. In A. Wilkinson, N. Bacon, T. Redman, \& S. Snell (Eds.), The SAGE Handbook of Human Resource Management: 12-30: Sage.

Gouldner, A. W. 1954. Patterns of Industrial Bureaucracy. New York: Free Press.

Grant, D., \& Shields, J. 2002. Researching employee reactions to human resources management. Journal of Industrial Relations, 44(3): 313-334.

Gratton, L., Hope-Hailey, V., Stiles, P., \& Truss, C. 1999. Strategic Human Resource Management: Corporate Rhetoric and Human Reality: Oxford University Press.

Grey, C. 2009. A very short, fairly interesting and reasonably cheap book about studying organisations (Second ed.). London: Sage.

Grimshaw, D. and Rubery, J. (2008) 'Economics and HRM', in P. Boxall, J. Purcell and P.M.

Wright (eds) Oxford Handbook of Human Resource Management. Oxford:

Oxford University Press.

Guest, D. 1987. Human resource management and industrial relations. Journal of

Management Studies, 24(5): 503-521.

Guest, D. 2011. Human resource management and performance: Still searching for some answers. Human Resource Management Journal, 21(1): 3-13.

Guest D 2017 Human Resource Management and Employee Well-Being: Towards a New Analytic Framework . Human Resource Management Journal,

Harley, B. 2015. 'The one best way?' 'Scientific' Research on HRM and the threat to critical scholarship. Human Resource Management, 25(4): 399-407.

Harney, B. 2009. Exploring the road less travelled in HRM-Performance research: A critical realist alternative to big science, Proceedings of the Labor and Employment Relations Association 61st Annual Meeting LERA. 
Harney, B., \& Jordan, C. 2008. Unlocking the black box: Line managers and HRM performance in a call centre context. International Journal of Productivity and Performance Management, 57(4): 275-296.

Harney, B., \& Trehy, J. 2016. Resource-based view. In A. Wilkinson, \& S. Johnstone (Eds.), Encyclopedia of Human Resource Management: 377-378: Edward Elgar.

Hassard, J. 2012. Rethinking the Hawthorne Studies: The Western Electric research in its social, political and historical context. Human Relations, 65(11): 1431-1461.

Heffernan, M., \& Dundon, T. 2016. Cross-level effects of high-performance work systems (HPWS) and employee well-being: the mediating effect of organisational justice. Human Resource Management Journal, 26(2): 211-231.

Huselid, M. A. 1995. The impact of human resource practices on turnover, productivity, and corporate financial performance. Academy of Management Journal, 38(3): 635-672.

Ichniowski, C., Shaw, C., \& Prennushi, G. 1997. The effects of human resource management on productivity: a study of steel finishing lines. American Economic Review, 87(3): 291-313.

Jackson, S. E., Schuler, R. S., \& Jiang, K. 2014. An aspirational framework for strategic HRM. Academy of Management Annals, 8(1): 1-56.

Jacques, R. 1999. Developing a tactical approach to engaging with 'Strategic' HRM. Organization, 6(2): 199-222.

Jiang, K., Lepak, D., Hu, J., \& Baer, J. 2012. How does human resource management influence organizaional outcomes? A meta-analytic investigation of mediating mechanisms. Academy of Management Journal, 55(6): 1264-1294.

Kaufman, B. 1999. Evolution and Current Status of University HR Programs. Human Resource Management Review, 38(2): 103-110.

Kaufman, B. 2007. The development of HRM in historical and international perspective. In P. Boxall, J. Purcell, \& P. Wright (Eds.), Handbook of Human Resource Management: 19-47. Oxford: Oxford University Press.

Kaufman, B. 2010. A theory of the firm's demand for HRM practices. International Journal of Human Resource Management, 21(5): 615-636.

Kaufman, B. 2012. Strategic Human Resource Management Research in the United States: A Failing Grade After 30 Years? Academy of Management Perspectives, May: 12-36.

Keegan, A., \& Boselie, P. 2006. The lack of impact of dissensus inspired analysis on developments in the field of human resource management. Journal of Management Studies, 43(7): 1491-1511.

Keenoy, T. 1990. HRM: rhetoric, reality and contradiction. International Journal of Human Resource Management, 1(3): 363-384.

Keenoy, T. 2007. Chasing the shadows of HRM. Paper presented at the Critical Management Studies Conference, University of Manchester, 11-13th of July.

Kiechel, W. I. 2012. The management century Harvard Business Review, November: 63-75.

Kochan, T. 2007. Social legitimacy of the HRM profession: A US perspective. In P. Boxall, J. Purcell, \& P. Wright (Eds.), Oxford Handbook of Human Resource Management. Oxford.

Legge, K. 1995. Human Resource Management: Rhetoric and realities. Basingstoke: Macmillan.

Legge, K. 2005. 'Preview/PostScript for the anniversary edition- Times they are a-changing: HRM Rhetoric and Realities Ten Years on', Human Resource Management. Basingstoke: Macmillan.

Lindblom CE (1959), 'The science of 'muddling through', Public Administration Review, 19

(Spring): 79-88. 
Marchington, M. 2015. Human resource management (HRM): Too busy looking up to see where it is going longer term? . Human Resource Management Review, 25(2): 176187.

Marchington, M., \& Suter, J. 2013. Where Informality Really Matters: Patterns of Employee Involvement and Participation (EIP) in a Non-Union Firm. Industrial Relations, 52(1): 284-313.

Marchington, M, Wilkinson, A, Donnely, R and Kynighou, A 2016, Human Resource Management at Work, 6th edition, London: Chartered Institute of Personnel and Development.

MacDuffie, J. P. 1995. Human resource bundles and manufacturing performance: organizational logic and flexible production systems in the world auto industry. Industrial and Labor Relations Review, 48(2): 197-221.

Miles, R., \& Snow, C. 1984. Designing strategic human resource systems. Organizational Dynamics, Summer: 36-52.

Mowday, R., Porter, L. W., \& Steers, R. 1982. Employee-organization linkages: The psychology of commitment, absenteeism, and turnover. New York: Academic Press.

Niven, M. 1967. Personnel management, 1913-63. The growth of personnel management and the development of the Institute. London: Institute of Personnel Management.

Nolan, P., \& Wood, S. 2003. Mapping the future of work. British Journal of Industrial Relations, 41(2): 165-174.

Paauwe, J., Guest, D., and Wright, P. (2013) HRM and performance: Achievements and challenges. Chichester: Wiley

Porter, M., \& Siggelkow, N. 2008. Contextuality within activity systems and sustainability of competitive advantage. Academy of Management Perspectives, 22(2): 34- 56.

Posthuma, R., Campion, M., Masimova, M., \& Campion, M. 2013. A High Performance Work Practices Taxonomy : Integrating the Literature and Directing Future Research. Journal of Management, 39(5): 1184-1220.

Ramsay, H., Scholarios, D., \& Harley, B. 2000. Employees and high performance work systems: testing inside the blackbox. British Journal of Industrial Relations, 38(4): 501-531.

Redman, T., Wilkinson, A., \& Dundon, T. 2017. Contemporary Human Resource Management (5th Edition ed.).

Schuler, R. S., \& Jackson, S. E. 1987. Linking competitive strategies with human resource management practices. Academy of Management Executive, 1: 207-219.

Seifert, R. (2015) 'Big Bangs and Cold Wars: the British industrial relations tradition after Donovan (1965-2015)', Employee Relations, 37(6): 746-760.

Storey, J. (Ed.). 1995. Human Resource Management: A Critical Text. London: Routledge.

Tamkin, P., Reilly, P., \& Hirsh, W. 2006. Managing and developing HR Careers: Emerging trends and issues: CIPD.

Torrington, D., Hall, L., Taylor, S., \& Atkinson, C. 2014. Human Resource Management. London: Pearson.

Townsend, K., \& Wilkinson, A. 2014. Guest Editors' Note: Time to Reconnect the Silos? Similarities and Differences in Employment Relations and Human Resources Human Resource Management, 53(2): 203-210.

Townsend, K. and Dundon, T. 2015. Guest editorial: Line Managers and Employee Relations, Employee Relations, 27(4):1-7.

Tyson, S. 1997. Human resource strategy: A process for managing the contribution of HRM to organisational performance. International Journal of Human Resource Management, 8(3): 277-290.

Tyson, S., \& Fell, A. 1986. Evaluating the Personnel Function. London: Hutchinson. 
van den Broek, D., \& Dundon, T. 2012. (Still) Up to No Good: Reconfiguring Worker Resistance and Misbehaviour in an Increasingly Unorganized World. Relations industrielles / Industrial Relations, 67(1): 97-121.

Wall, T., \& Wood, S. 2005. The romance of human resource management and business performance, and the case for big science. Human Relations, 58(4): 429-462.

Walton, R. E. 1985. From control to commitment on the workplace. Harvard Business Review, 63: 77-84.

Wilkinson, A., Bacon, N., Redman, T., \& Snell, S. 2009. The SAGE Handbook of Human Resource Management: Sage.

Wood, S. 1979. A reappraisal of the contingency approach to organisation. Journal of Management Studies, 16(3): 334-354. 